\author{
Cadernos de \\ ESTUDOS LINGülíSTICOS - (56.1), Campinas, Jan./Jun. 2014
}

\title{
TWO NOMINALIZING SUFFIXES IN BRAZILIAN PORTUGUESE: LOCALITY CONSTRAINTS ON MORPHOPHONOLOGICAL REALIZATION
}

\author{
MARIA LUISA FREITAS* \\ IEL/UNICAMP
}

\begin{abstract}
RESUMO: Este artigo discute os aspectos morfofonológicos de dois sufixos nominalizadores no Português Brasileiro: -ção e -mento. Tendo em vista um modelo sintático de formação de palavras como o proposto pela Morfologia Distribuída e assumindo que a derivação sintática procede em termos de fases, argumentamos que os aspectos morfofonológicos dessas nominalizações são o resultado de duas propriedades sintáticas: primeiro, o tipo de estrutura argumental do verbo; e segundo, o ponto na derivação no qual a estrutura sintática é enviada ao componente fononlógico.

Palavras chave: Vogal temática; alomorfia condionada pela raiz; domínios cíclicos.
\end{abstract}

RESUMEN: Este artículo discute los aspectos morfofonológicos de dos sufijos nominalizadores en el portugués brasileño: -ção y -mento. Adoptando un modelo sintáctico de formación de palabras como el de la Morfología Distribuída, y asumiendo que la derivación sintáctica se desarrolla por fases, argumentamos que los aspectos morfofonológicos de estas nominalizaciones son el resultado de dos propriedades sintácticas: primero, la estructura argumental del verbo; y segundo, el punto de la derivación en que la estructura sintáctica es enviada a la interfaz FF.

Palabras clave: vocal temática; alomorfía condicionada por la raíz; dominios cíclicos

\section{INTRODUCTION}

Nominalizations have taken a central role in linguistic theory, as they involve crosslinguistically different structures that show non-homogeneous behavior (Chomsky 1970; Grimshaw 1992). Alexiadou and Rathert (2010) recognize two main models which attribute the argument structure in the nominal domain from different theoretical viewpoints of the representation: the lexicalist model and the structural/syntactic model. Taking Grimshaw (1992) as representative of the first model, it is possible to say that nouns inherit their argument structure from the embedded verb in the lexicon. Therefore, possible ambiguities (event vs. result readings of the nouns, for instance) occur in virtue of the event structure attributed to the lexical representation of the noun. The

* I would like to thank Andrew Nevins, Ana Paula Scher, Aroldo Andrade and Norvin Richards for the careful reading of this paper, contributing important suggestions and clarifications. I also thank Frederico Coutinho for the helpful contribution to the statistical analysis. 
second model, on the other hand, argues that the presence of argument structure follows from the existence of a VP node (or some functional projection of VP) inside the nominal structure (see Alexiadou 2001; Embick 2000; 2004). In other words, the event interpretation is made possible by the presence of verbal functional layers within the nominal structure. Interestingly, both models agree on the idea that the nominal argument structure is inherited from the verb. Alexiadou and Rathert (2010) claim that only nominals that have been verbs as part of their derivational history can license argument structure. This suggests a strict relationship between morphology and meaning.

In this paper, taking into account a syntactic model of word formation such as Distributed Morphology (Halle; Marantz 1993; 1994; among many others), I argue that the argument structure of deverbal nouns is also responsible for the morphophonological behavior of competing morphemes, in addition to any possible effect of event semantics. To do so, I analyze two nominalizing suffixes in Brazilian Portuguese (henceforth BP): -ção and-mento. These suffixes are described together as the most productive nominalizing suffixes in BP (Rocha 2003 apud Santos 2006). These suffixes can take both roots and verbs to form derived nouns. Besides, they can describe (i) actions; (ii) results of a process; (iii) states (Santos 2006). In spite of having similar semantic properties, they exhibit subtle differences, as the following examples show.

(1) a. A medicação dos pacientes demorou muito tempo.

"The medication of the patients took a long time."

b. ? O medicamento dos pacientes demorou muito tempo.

"The medicine/medicament of the patients took a long time"

(2) a. A afinação da guitarra demorou muito tempo.

"The tuning of the guitar took a long time."

b. ? O afinamento da guitarra demorou muito tempo.

"The tuning of the guitar took a long time"

In cases of doublets, I note that nouns formed by -ção facilitate/permit the eventive reading, taking arguments as complements, while the nouns formed by -mento do not. As Alexiadou and Martin (2012) point out the phenomenon of deriving sets of two or more synonymous words from the same stem with different affixes is rather common crosslinguistically. In this paper, I focus on the morphophonological aspects of nouns formed by these two suffixes, such as: (i) the neutralization of the verbal theme vowels $-i$ - and $-e-$; and (ii) contextual allomorphy conditioned by the root. Assuming that the syntactic derivation proceeds in terms of phases (Chomsky 2000, 2001), sent cyclically to the phonological component, I take the morphophonological differences related to -mento and-ção nouns to be the surface result of two syntactic properties: first, the argument structure type of the embedded verb; and second, the derivational point at which the syntactic structure is sent to PF. 
The quantitative data I focus on derives from a database of 2715 words collected from the electronic version 1.0 of the Houaiss Dictionary of Portuguese [Dicionário Eletrônico Houaiss da Língua Portuguesa 1.0]. Our analysis intends to explain the patterns and tendencies found within the sample.

This paper is organized as follows: in section 2, I describe general aspects of the suffixes -ção and - mento; in section 3, I present the theoretical hypotheses and the methodological procedure of the database construction; in section 4, I discuss the main results of the database analysis; in section 5, I theoretically interpret the facts found in database analysis; and finally, in section 6, I conclude the article.

\section{2. -mento and -ção: an overview}

As already noted, the suffixes - mento and -ção can be attached to both roots and verbs to form derived nouns. Out of these, I focus on deverbal derivational contexts, where these suffixes share the semantic properties of describing actions, results of a process, or states ${ }^{1}$. In the following subsections, I discuss specific the properties of each suffix.

\subsection{The suffix -mento}

This suffix forms derived masculine nouns from verbal bases, as the following examples ${ }^{2}$ show.

Verbal Base
a. afundar
"to sink"
b. dilacerar
"to lacerate"
c. amarelecer "to yellow"
d. assentar "to settle"
e. aprisionar "to imprison"
f. obscurecer "to obscure"
g. sofrer
"to suffer"
h. aquecer "to warm"
i. ferir
"to hurt"
j. florescer "to flourish"

\section{Noun}

$\begin{array}{cc}\text { afundamento } & \text { "sinking" } \\ \text { dilaceramento } & \text { "laceration" } \\ \text { amarelecimento } & \text { "yellowing" } \\ \text { assentamento } & \text { "settlement" } \\ \text { aprisionamento } & \text { "imprisonment" } \\ \text { obscurecimento } & \text { "obscuration" } \\ \text { sofrimento } & \text { "suffering" } \\ \text { aquecimento } & \text { "warming" } \\ \text { ferimento } & \text { "wound" }\end{array}$

florescimento "flourishing"

\footnotetext{
${ }^{1}$ See Basílio (1994) and Rocha (1999) on semantic properties of nominalizing suffixes in BP.

${ }^{2}$ All examples shown in this paper present forms collected in the database sample.
} 
As we can observe in (3), the formation of -mento nouns presents the following structure: Verbal base ${ }^{3}+$ Theme Vowel +-mento. This structure is quite regular in all deverbal nouns formed by -mento. These nouns may refer to the product, tool or local of the verbal action (Santos 2006), in addition to the semantic properties shared with -ção (i.e. actions; results of a process; and states). They present the gender feature [masculine] and can be pluralized:

(4) a. o casamento

DET/MASC/SG-marriage/wedding

"The marriage/wedding"

b. os casamentos

DET/MASC/PL-marriages/weddings

"The marriages/weddings"

(5) a. o nascimento

DET/MASC/SG-birth

"The birth"

b. os nascimentos

DET/MASC/PL- birth

"The births"

Santos (2006) points out that -mento nouns exhibit some preferences and some restrictions of occurrence relating to particular classes of verbal bases ${ }^{4}$ :

(6) Preferences:
a. -ecer
emagrecer-emagrecimento
"to lose weight - "weight-loss"
amarelecer - amarelecimento
"to yellow - yellowing"
b. -ciar/cionar
estacionar - estacionamento
"to park - parking"
funcionar-funcionamento
"to work/to function - working/functioning"

${ }^{3}$ I assume that the verbal base is composed of a root and a verbalizing head: $v[v \sqrt{\operatorname{Root}}]$.

${ }^{4}$ Gamarski (1984) describes a preference relationship between the -mento nouns and the verbal bases in-ear. The author also notes that these nouns exhibit a preference for parasynthetic and prefixed verbs. In this paper, I did not include these observations in the database analysis. However, it will be focused in future research. It is important to mention that the Houaiss Dictionary also attests the form lambeção without raising of the theme vowel. 


\section{(7) Restrictions:}

a. -izar

comercializar - *omercializamento

"to comercialize" - not attested

\section{b. -mentar}

fundamentar - *fundamentamento

"to justify" - not attested

In the database, I found that -mento nouns correspond more frequently to verbs ending in -ecer class. They systematically do not correspond to verbs ending with -izar class. Both -ciar/-cionar and -mentar classes did not demonstrate a relevant frequency of occurrence. I discuss these results in detail in section 4.

There is an interesting issue related to the theme vowels. Romance languages idiosyncratically classify verbs as belonging to a particular conjugation class. This classification is based on the theme vowel (Oltra-Massuet 1999). In BP, there are four thematic classes of verbs:

(8) a. Class I - Theme vowel -a-: cant-a-r [kən.'tah] "to sing"

b. Class II - Theme vowel -e-: corr-e-r [ko.siheh] "to run"

c. Class III - Theme vowel -i-: dorm-i-r [doh.'mih] "to sleep"

d. Class IV - Theme vowel -o-: rep-o-r [he.'poh] "to replace"

As we have seen, in such deverbal nouns formed by -mento the verbal theme vowel is maintained. However, there is an interesting morphophonological phenomenon: the theme vowel /e/ undergoes an obligatory raising to [i], resulting in neutralization between the classes II and III.

(9) a. mo-e-r-mo-i-mento

"to grind" - "grinding"

b. $f a z-e-r-f a z-i-m e n t o$

"to do-doing"

c. bat-e-r-bat-i-mento

"to beat/knock - beating"

Such neutralization is a phenomenon quite recurrent in BP. For instance, regular participles exhibit only two forms: -ado for Class I; and -ido for Classes II and III.

(10) a. cantar-cantado; amar-amado; chorar-chorado

"to sing - sung"; "to love - loved"; "to cry - cried"

b. correr-corrido; trazer - trazido; comer - comido

"to run - run"; "to bring - brought"; "to eat - eaten" 
c. dormir - dormido; fugir-fugido; sair-saido

"to sleep - slept"; "to escape - escaped"; "to leave - left"

Also, there are some deverbal adjectives that involve two derivational suffixes: -ável for Class I; and -ível for Classes II and III.

(11) a. cantar - cantável; amar - amável; achar - achável

"to sing - singable"; "to love - lovable"; "to find - findable

b. comer-comivel; beber-bebivel; conhecer-conhecivel

"to eat - eatable"; "to drink - drinkable"; "to know - knowable"

c. falir-falível; digerir-digerivel; discutir-discutivel "to fail - fallible; "to digest - digestible"; "to discuss - discussable"

The deverbal nouns formed by -ção do not present such obligatory neutralization, as we will discuss in the next section. This contrast must be explained.

\subsection{The suffix $-c ̧ \tilde{a} o$}

This suffix forms derived feminine nouns from verbal bases, as the following examples show.

\section{Verbal Base}

$\begin{array}{lcc}\text { a. } & \text { admirar } & \text { "to admire" } \\ \text { b. } & \text { perseguir } & \text { "to pursue" } \\ \text { c. formalizar } & \text { "to formalize" } \\ \text { d. } & \text { privatizar } & \text { "to privatize" } \\ \text { e. } & \text { difamar } & \text { "to defame" } \\ \text { f. } & \text { obrigar } & \text { "to oblige" } \\ \text { g. } & \text { declinar } & \text { "to decline" } \\ \text { h. } & \text { conversar } & \text { "to talk" } \\ \text { i. } & \text { inibir } & \text { "to inhibit" } \\ \text { j. } & \text { elevar } & \text { "to elevate" }\end{array}$

\section{Noun}

$\begin{array}{cc}\text { admiração } & \text { "admiration" } \\ \text { perseguição } & \text { "persecution" } \\ \text { formalização } & \text { "formalization" } \\ \text { privatização } & \text { "privatization" } \\ \text { difamação } & \text { "defamation" } \\ \text { obrigação } & \text { "obligation" } \\ \text { declinação } & \text { "declination" } \\ \text { conversação } & \text { "conversation" } \\ \text { inibição } & \text { "inhibition" } \\ \text { elevação } & \text { "elevation" }\end{array}$

In most cases, the structure of these nouns is: Verbal base + Theme Vowel+ -ção. The database reveals that only in few cases the deverbal nouns do not maintain a complete identity with the verbal base. This generally occurs when the last syllable of the verbal base begins with a fricative segment. In such contexts, the last syllable of the verb is suppressed in the derived noun.

\section{a. corrigir - correção, *corregição}

"to correct - correction" 
b. locomover - locomoção *locomoveção

"to move - locomotion"

c. maldiżer - maldição * maldizeção

"to curse - curse"

d. distorçer - distorção *distorceção

"to distort - distortion"

As I pointed out, the nouns formed by -ção exhibit semantic properties of action, process and/or state, allowing an eventive reading of predicate. They show the gender feature [feminine] and can also be pluralized.

(14) a. a medicação

DET/FEM/SG-medication

"The medication"

b. as medicações

DET/FEM/PL-medications

"The medications"

(15) a. a reivindicação

$\mathrm{DET} / \mathrm{FEM} / \mathrm{SG}$-claim

"The claims"

b. as reivindicações

$\mathrm{DET} / \mathrm{FEM} / \mathrm{PL}$-claims

"The claims"

Santos (2006) observes that -ção nouns also exhibit some preferences and some restrictions of occurrence relating to particular classes of verbal bases. Interestingly, there is a complementarity between the two suffixes: the classes preferably selected by one suffix are restricted in the use of the other suffix, and vice-versa.

\section{(16) Preferences:}

\section{a. -izar}

comercializar - comercialização

"to comercialize" - "commercialization"

centralizar - centralização

"centralize" - "centralization"

\section{b. -mentar}

fundamentar - fundamentação

"to justify" - "grounding"

movimentar - movimentação

"to move"-"movement" 


\section{(17) Restrictions:}

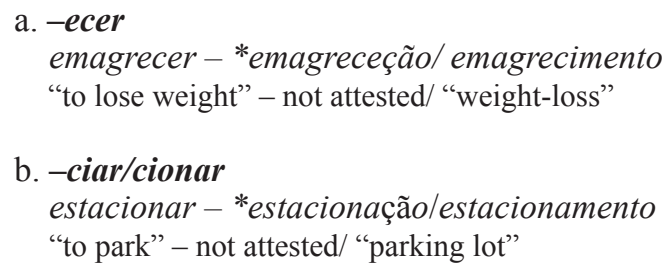

As mentioned, the verbal theme vowels are maintained in the deverbal nouns formed by -mento and -ção. However, unlike the -mento nouns, the theme vowel /e/ of the -ção nouns does not undergo obligatory raising to [i].
a. comer - começão/*comição
"to eat - eating"
b. fazer - fazeção/ *fazição (cf. fazimento)
"to do - doing"
c. bater - bateção/*batição (cf. batimento)
"to beat/knock - beat"

This fact strongly suggests transparency of -ção regarding the neutralization of classes II and III. The question that thus arises is, if there is a rule in the language that neutralizes classes II and III of verbal theme vowels in non-verbal environments, why is -ção immune to that?

\section{HYPOTHESES AND METHODOLOGY}

In this section, I discuss our working hypothesis and describe the methodological aspects of our database construction. As described in the previous section, I intend to explain the complementary behavior of -ção and -mento regarding: (i) neutralization of classes II and III of theme vowels; and (ii) contextual allomorphy conditioned by the root. In this work, these aspects are investigated with evidence from the following theoretical hypotheses:

(H1) There is a tight relation between morphophonological aspects of -ção and -mento nouns and the syntactic structure they enter in.

(H2) Different types of the embedded verb argument structure are responsible for surface features of suffixes.

(H3) The derivational point at which the embedded root of -ção and -mento are sent to $\mathrm{PF}$ is different. 
These hypotheses are dependent: 03 is true if and only if 02 is true; and 02 is true if and only if 01 is true. Thus, 01 is a sine qua non condition for the truth of 02 and 03 , but it is not a sufficient condition, once there are other possible factors acting on the truth relations of each hypothesis.

In order to verify our hypotheses, I have developed a database using the electronic version 1.0 of Houaiss Dictionary of Portuguese [Dicionário Eletrônico Houaiss da Lingua Portuguesa1.0]. In such dictionary, there are 4580 words that present the -ção suffix and 2772 words that show the -mento suffix (=7352 words). Using the software SPSS Statistics Data Editor I have generated a random sample of approximately $37 \%$ of this universe of words. This percent constitutes a total of 2715 words ( 1045 words formed by -mento and 1670 formed by $-c ̧ a \tilde{o}$ ).

From this sample, I have excluded all the words not derived from verbal bases, such as fragmento "fragment", argumento "argument", vegetação "vegetation", cupim-cabeção "big-headed termite", etc. I also excluded all the words whose verbal base did not have an individual entry in the dictionary. In such cases, the dictionary normally suggests a possible verbal base, however, this base is not attested (for instance, hadronização "hadronization" $=>$ *hadronizar not attested). The excluded cases resulted a total of 540 words. The Table 1 shows the distribution of the entries effectively in the analysis.

Table 1: Distribution of selected cases

\begin{tabular}{l|c|c}
\hline \multicolumn{1}{c|}{ Suffixes } & $\mathbf{N}$ & $\mathbf{\%}$ \\
\hline mento & 941 & 43,3 \\
$c \tilde{a} \boldsymbol{o}$ & 1.234 & 56,7 \\
Total & 2.175 & 100,0 \\
\hline
\end{tabular}

Within the total of words (i.e. 2175 words), there are 180 cases in which the verbal base was selected twice in the sample, in virtue of doublets. In order to not overestimate the results, in some tables in which the verbal base was the focus of the analyses, I included these verbal bases only once. In such situations, I considered 2085 cases ( $=2175-90$ repeated verbs). I have categorized the sample according to the following variables:

\section{(19) Variables}

01. SufFIX: this variable indicates the type of suffix (-ção or -mento).

02. Verbal Base: this variable indicates the verbal base which the -ção and -mento nouns are derived from.

03. DoubLET: this variable indicates if the noun shows or not a doublet, formed with the other suffix out of the same verbal base. For example: afinação/ afinamento "tuning"; afirmação/afirmamento "affirmation"; etc.

04. Theme Vowel: this variable indicates the theme vowel $\{-\mathrm{a}-,-\mathrm{e}-,-\mathrm{i}-,-\mathrm{o}-\}$ of the verbal base. 
05. VOWEL RAISING: this variable indicates if the theme vowel -e- raises or not to closed vowel [i] in the nouns formed by -ção and -mento. For example: moer "to grind" => moeção/moimento "grinding".

06. VERB TYPE: this variable indicates if the verbal base is transitive, intransitive or both. The intransitive category was subdivided into unergative and unaccusative.

07. Verbal Suffixes: this variable indicates the suffixes of the verbal bases.

08. IDENTITY WITH THE BASE: this variable indicates if the derived noun has identity with the verbal base or not in one or both derivates; that is, if the noun preserves the same phonological features of the base or not. For example: absorver "to absorb"=> absorvimento/absorção "absorption".

Taking into account these variables and our theoretical hypothesis, I computed the frequencies of all variables in order to measure the distribution and the percent of the observed morphophonological phenomena. Additionally, I conducted crosstabulations to verify the relations between the variables. For every crosstabulation table in which all cells show at least five cases, I have also conducted a Chi-square test. Chi-square is a non-parametric test that allows one to verify the existence of statistical association between two nominal variables. The null hypothesis to be tested is that the two variables are not associated, i.e. they are independent. Therefore, the alternative hypothesis is that the two variables are associated. These tests are discussed in the following section.

\section{MAIN RESULTS}

In this section, I discuss the main results found from the analysis of the database. This section is divided up into four subsections: (i) results related to the theme vowels and, especially, the vowel -e-; (ii) results regarding the suffixes of verbal bases; (iii) results relating the verbal base types; and (iv) additional results.

\subsection{Theme vowels}

According to the Houaiss Dictionary, the verbs in BP exhibit the following distribution of theme vowels:

Table 2: Total distribution of verbs (-ar, -er, -ir, -or)

\begin{tabular}{l|c|c}
\hline Theme vowels & $\mathbf{N}$ & $\mathbf{\%}$ \\
\hline $\mathrm{a}$ & 13.011 & 89,2 \\
$\mathrm{e}$ & 788 & 5,4 \\
$\mathrm{i}$ & 742 & 5,1 \\
o & 40 & 0,3 \\
Total & 14.581 & 100,0 \\
\hline \multicolumn{2}{c}{ Sources: Houais s Dictionary of Portuguese }
\end{tabular}


As we can note in Table 2, there is an unequal distribution of verbs between the conjugation classes: the verbs which have the theme vowel -a- sum to almost $90 \%$, and the remaining $10 \%$ of verbs are divided among the other three conjugations. In the database, the distribution of verbs relating to theme vowels is quite similar to the total of verbs, as we can see in Table 3.

Table 3: Distribuition of verbs in the sample (-ar, -er, -ir, -or)

\begin{tabular}{l|c|c}
\hline \multicolumn{1}{c|}{ Theme vowels } & $\mathbf{N}$ & $\mathbf{\%}$ \\
\hline $\mathrm{a}$ & 1.838 & 88,2 \\
$\mathrm{e}$ & 133 & 6,4 \\
$\mathrm{i}$ & 107 & 5,1 \\
$\mathrm{o}$ & 7 & 0,3 \\
Total & 2.085 & 100,0 \\
\hline
\end{tabular}

However, I observe a change in distribution from the crosstabulation of the dependent variable by the theme vowel. The proportion of verbs with theme vowel -e- is higher in the group of -mento verbal bases than in the group of -ção, in a significant amount of the data, as we can see in Table 4.

Table 4: Crosstabulation Theme Vowel vs. Suffix (ção, mento)

\begin{tabular}{ll|c|c|c}
\hline \multicolumn{2}{c|}{ Theme Vowels } & \multicolumn{2}{c|}{ Suffix } & \multirow{2}{*}{ Total } \\
\hline \multirow{2}{*}{ a } & $\mathrm{N}$ & mento & ção & \\
\cline { 2 - 4 } & $\%$ within $\mathrm{TH}$ & 740 & 1.098 & 1.838 \\
\hline \multirow{2}{*}{$\mathrm{e}$} & $\mathrm{N}$ & $40,3 \%$ & $59,7 \%$ & $100,0 \%$ \\
\cline { 2 - 4 } & $\%$ within $\mathrm{TH}$ & 106 & 27 & 133 \\
\hline \multirow{2}{*}{$\mathrm{i}$} & $\mathrm{N}$ & $79,7 \%$ & $20,3 \%$ & $100,0 \%$ \\
\hline \multirow{2}{*}{$\mathrm{O}$} & $\%$ within $\mathrm{TH}$ & 39 & 68 & 107 \\
\hline \multirow{2}{*}{ Total } & $\mathrm{N}$ & $36,4 \%$ & $63,6 \%$ & $100,0 \%$ \\
\cline { 2 - 4 } & $\%$ within $\mathrm{TH}$ & 0 & 7 & 7 \\
\hline
\end{tabular}

The results for the theme vowel -e- are the following: almost $80 \%$ of verbs select the -mento suffix, and only $20 \%$ of these verbs select the $-c ̧ \tilde{a} o$ suffix. This difference in distribution seems to indicate a preference relation between the suffix -mento and the verbs of II conjugation (theme vowel -e-). It should be mentioned that only one case of these 106 verbs (theme vowel -e-/ -mento group) shows a

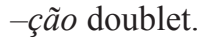


As mentioned, in order to verify the dependence relation between these two variables, I have computed a Chi-square test. To do so, I have excluded the category -o- on theme vowel variable, since it has less than five cases within the -mento group. For the variables shown in Table 4 (except the category theme vowel -o-), the Chi-square result is the following: Pearson Chi-square $=\mathbf{7 9 , 2 6 7}$ with 2 degrees of freedom, $\mathrm{p}<0,000$. This result allows me to reject the null hypothesis (i.e. the variables are independent) and corroborates the alternative hypothesis (i.e. the variables are associated) with over $99 \%$ reliability.

With respect to the raising of the theme vowel -e-, I have found evidence for its obligatoriness within the -mento group. Once there are fewer overall instances of this vowel within the -ção group, I observed only six cases of theme vowel raising in such group, as I show in Table 5.

Table 5: Crosstabulation Raising of theme vowel -e- vs. (ção, mento)

\begin{tabular}{ll|c|c|c}
\hline \multirow{2}{*}{ Suffix (ção, mento) } & \multicolumn{2}{c|}{$\begin{array}{c}\text { Raising of theme } \\
\text { vowel -e- }\end{array}$} & \multirow{2}{*}{ Total } \\
\cline { 3 - 4 } & & Yes & No & \\
\hline \multirow{2}{*}{-mento } & $\mathrm{N}$ & 108 & 0 & 108 \\
\cline { 2 - 4 } & $\%$ within Suffix & $100,0 \%$ & $0 \%$ & $100,0 \%$ \\
\hline \multirow{2}{*}{-ção } & $\mathrm{N}$ & 6 & 21 & 27 \\
\cline { 2 - 4 } & $\%$ within Suffix & $22,2 \%$ & $77,8 \%$ & $100,0 \%$ \\
\hline \multirow{2}{*}{ Total } & $\mathrm{N}$ & 114 & 21 & 135 \\
\cline { 2 - 4 } & $\%$ within Suffix & $84,4 \%$ & $15,6 \%$ & $100,0 \%$ \\
\hline
\end{tabular}

Interestingly, these results show that within the group -mento there is a preference for verbal bases of the II conjugation. Further, the raising of theme vowel -e- in this group is a categorical phenomenon. That is, this group follows a phonological rule that neutralizes class II and III of theme vowels in non-verbal environments (e.g. regular participle forms). The-ção group, however, shows a low occurrence of II conjugation verbs and does not trigger raising of theme vowel -eobligatorily. The only six exceptions are: perder "to lose" => perdição "perdition"; lamber "to lick"=> lambição "licking"; reeleger "to re-elect" => reeleição "reelection"; retrovendição "buy back" => retrovender "buy back"; revendição "resale" => revender "resell"; recognição "recognition" => reconhecer "recognize".

\subsection{Suffixes of verbal bases}

As I discussed in section 2, Santos (2006) describes a complementarity between -ção and -mento regarding different classes of verbs: (i) -ção: preferably chooses the verbal suffixes -izar and -mentar and presents restrictions of use with-ecer and-ciar/cionar; while (ii) -mento: preferably chooses the verbal suffixes -ecer and-ciar/cionar and presents restrictions of use with-izar and-mentar.

${ }^{5}$ It is important to mention that the Houaiss Dictionary also attests the form lambeção without raising of the theme vowel. 
In the database, I have found a heterogeneous distribution of verbal suffixes in virtue of a considerable number of distinct verbal bases. Hence, I focus on the suffixes mentioned by Santos (2006). These suffixes have shown the following distribution (in relation to the variable suffix):

Table 6: Crosstabulation Verbal bases (-ciar, -mentar -cir/-cionar, -ecer) vs. Suffix (ção, mento)

\begin{tabular}{|c|c|c|c|c|}
\hline \multirow{2}{*}{\multicolumn{2}{|c|}{ Verbal bases }} & \multicolumn{2}{|c|}{ Suffix } & \multirow{2}{*}{ Total } \\
\hline & & mento & ção & \\
\hline \multirow{2}{*}{$-i z a r$} & $\mathrm{~N}$ & 11 & 230 & 241 \\
\hline & $\%$ within Verbal base & $4,6 \%$ & $95,4 \%$ & $100,0 \%$ \\
\hline \multirow{2}{*}{-mentar } & $\mathrm{N}$ & 0 & 19 & 19 \\
\hline & $\%$ within Verbal base &, $0 \%$ & $100,0 \%$ & $100,0 \%$ \\
\hline \multirow{2}{*}{-cionar, -ciar } & $\mathrm{N}$ & 22 & 19 & 41 \\
\hline & $\%$ within Verbal base & $53,7 \%$ & $46,3 \%$ & $100,0 \%$ \\
\hline \multirow{2}{*}{-ecer } & $\mathrm{N}$ & 53 & 1 & 54 \\
\hline & $\%$ within Verbal base & $98,1 \%$ & $1,9 \%$ & $100,0 \%$ \\
\hline
\end{tabular}

The -izar class has presented a frequency (230 cases) relatively high in relation to the others. There is a quite clear tendency of -izar verbs to occur with -ção group $(95,4 \%)$. Despite the low frequency of the -mentar ending, all registered cases in the database occurred with the -ção group. The -ciar and cionar suffixes together total 41 cases in the sample. Despite their low frequency, it should be noted a slight preference for the-mento group. Almost all cases which presented the -ecer ending occurred in the -mento group. The only exception is word recognição "recognition" => reconhecer "recognize".

\subsection{Types of verbs}

In order to classify data for this variable I followed the classification regarding verbal valence presented in the Houaiss Dictionary. Thus, I created two binary (yes-no) variables: transitive and intransitive. Therefore, a single verb (depending on different semantic contexts) could be transitive or intransitive or both. Obviously, the dictionary does not present a sub-classification of intransitive verbs into unaccusative and unergative. Hence, I categorized the verbs into these two types of intransitives applying some diagnostics described in the literature (cf. Levin; Rappaport-Hovav 1995; Hale; Keyser 1993, 1998, 2002; Duarte, 2003): (i) transitive-inchoative alternations - only unaccusative verbs are able to participate in transitive-inchoative alternations (e.g. A manteiga derreteu "the butter melted"/ O calor derreteu a manteiga "the heat melted the butter"). (ii) Constructions with absolute participles: in Portuguese, only unaccusatives take part in constructions with absolute participles (e.g Nascida a criança ontem "born 
the child yesterday"/ *Corrida a criança ontem "running the child yesterday"). (iii) Constructions with the agentive suffix -or: in most cases, only transitives and unergatives accept nominalization via the agentive suffix -or (e.g. correr "to run" => corredor "runner"; nascer "to born" $=>$ *nascedor - not attested). Thereby, one and the same verb, if classified as intransitive, was further classified as unergative or unaccusative. The frequencies found for the different categories of verbs are the following.

Table 7: Frequency of Verbs

\begin{tabular}{l|c|c}
\hline \multicolumn{1}{c|}{ Category of verbs } & $\mathbf{N}$ & $\mathbf{\%}$ \\
\hline Transitive and intransitive & 752 & 36,1 \\
\hline Only transitive & 1.256 & 60,2 \\
\hline Only Intransitive & 77 & 3,7 \\
\hline Total & 2.085 & 100,0 \\
\hline
\end{tabular}

Table 07 indicates a predominance of verbs exclusively transitives $(60,2 \%)$. There are $36,1 \%$ of verbs that alternate between transitive and intransitive structures depending on the semantic contexts and almost $4 \%$ of verbs exclusively intransitives. Table 08 below shows the crossing of these three categories of verbs and variable suffix.

Table 8: Crosstabulation Categories of verbs vs. Suffix (-ção, -mento)

\begin{tabular}{ll|c|c|c}
\hline \multirow{2}{*}{ Types of verbs } & \multicolumn{2}{c|}{ Suffix (ção, mento) } & \multirow{2}{*}{ Total } \\
\cline { 3 - 4 } & mento & ção & \\
\hline $\begin{array}{l}\text { Transitive and } \\
\text { intransitive }\end{array}$ & $\mathrm{N}$ & 409 & 343 & 752 \\
\cline { 2 - 4 } \% within Verbs & $54,4 \%$ & $45,6 \%$ & $100,0 \%$ \\
\hline \multirow{2}{*}{ Only transitive } & $\mathrm{N}$ & 448 & 808 & 1.256 \\
\cline { 2 - 4 } Only intransitive & $\%$ within Verbs & $35,7 \%$ & $64,3 \%$ & $100,0 \%$ \\
\hline \multirow{2}{*}{ Total } & $\%$ within Verbs & $36,4 \%$ & $63,6 \%$ & $100,0 \%$ \\
\hline
\end{tabular}

In both categories of verbs exclusively transitive and exclusively intransitive there is a preference for the -ção suffix. In the first category, in which the verbs can be transitive and intransitive, there is a slighter preference for the -mento suffix. Interestingly, the two categories of intransitive verbs show a distinct pattern in relation to the suffix choice. However, if we consider the distribution of unergative and unaccusative types within the intransitives, this pattern may be elucidated, as we can verify in Table 9 and 9.1 below. 
Cadernos de ESTUDOS LINGü̈ISTICOS (56.1) - Jan./Jun. 2014

Table 9: Intransitive Verbs* vs. Suffix (ção, mento) Crosstabulation

\begin{tabular}{ll|c|c|c}
\hline \multirow{2}{*}{ Intransitive Types } & \multicolumn{2}{c|}{ Suffix (ção, mento) } & \multirow{2}{*}{ Total } \\
\cline { 3 - 4 } & mento & ção & \\
\hline \multirow{2}{*}{ Unergative } & Count & 114 & 239 & 363 \\
\cline { 2 - 4 } & $\%$ within Verb & $32,3 \%$ & $67,7 \%$ & $100,0 \%$ \\
\hline \multirow{2}{*}{ Unaccusative } & Count & 323 & 154 & 477 \\
\cline { 2 - 4 } & $\%$ within Verb & $67,7 \%$ & $32,3 \%$ & $100,0 \%$ \\
\hline \multirow{2}{*}{ Total } & Count & 437 & 393 & 830 \\
\cline { 2 - 4 } & $\%$ within Verb & $52,7 \%$ & $47,3 \%$ & $100,0 \%$ \\
\hline
\end{tabular}

* All intransitive verbs ("Only Intransitive" and "Transitive Intransitive" categories)

Table 9.1: Crosstabulation "Only Intransitive" Category vs. Suffix

\begin{tabular}{ll|c|c|c}
\hline \multirow{2}{*}{ Intransitive Types } & \multicolumn{2}{c|}{ Suffix (ção, mento) } & \multirow{2}{*}{ Total } \\
\cline { 3 - 4 } & mento & ção & \\
\hline \multirow{2}{*}{ Unergative } & Count & 18 & 43 & 61 \\
\cline { 2 - 4 } & $\%$ within Verb & $29,5 \%$ & $70,5 \%$ & $100,0 \%$ \\
\hline \multirow{2}{*}{ Unaccusative } & Count & 10 & 6 & 10 \\
\cline { 2 - 4 } \% within Verb & $62,5 \%$ & $37,5 \%$ & $100,0 \%$ \\
\hline \multirow{2}{*}{ Total } & Count & 28 & 49 & 77 \\
\hline & $\%$ within Verb & $36,4 \%$ & $63,6 \%$ & $100,0 \%$ \\
\hline
\end{tabular}

In both Tables 9 and 9.1, it is possible to see a clear tendency indicating that unaccusative verbs preferably selects the -mento suffix and unergative verbs preferably selects the $-c ̧ \tilde{a} o$ suffix. The Chi-square result for the crosstabulation in Table 10 is: Pearson Chi-square $=\mathbf{1 0 2 , 0 9 4}$ with 1 degree of freedom, $\mathrm{p}<0,000$. This means, with $99 \%$ reliability, that the two variables are associated. In Table 10.1, the Chi-square result is: Pearson Chi-square $=\mathbf{5 , 9 6 9}$ with 2 degree of freedom, $\mathrm{p}<0,020$. It indicates that the two variables are associated with $95 \%$ reliability.

\subsection{Additional results}

In this subsection, I discuss two additional results I found for "doublet" and "identity with the base" variables. First, I present in Table 10 the frequency of doublets found in the database. 
Table 10: Frequency of Doublets

\begin{tabular}{l|c|c|c}
\hline Doublets & $\mathbf{N}$ & $\mathbf{\%}$ & Valid \% \\
\hline Yes & 346 & 15,9 & 16,6 \\
No & 1739 & 80,0 & 83,4 \\
Total & 2085 & 95,9 & 100,0 \\
\hline $\begin{array}{l}\text { The two forms were } \\
\text { selected in the sample }\end{array}$ & 90 & 4,1 & \\
Total & 2175 & 100,0 & \\
\hline
\end{tabular}

Oliveira (2007) proposes that there are semantic restrictions acting on the choice of -ção and -mento by different verbal bases. She argues that -ção takes agentive/causative verbs, while -mento takes non-agentive/non-causative verbs.

The proposal is general correct, from the results from Table 11; however, she considers as exception the existence of doublets, mentioning only three cases. Our data shows, however, a percent of $16,6 \%$ (= 346 cases) of doublets. Considering this sample to be representative of the universe of words, it is difficult to claim this percent as exceptional. It would be necessary to include an explanation for why almost $17 \%$ of verbal bases accept doublets. A potential hypothesis, to be pursued in future works, regards the different readings (event vs. result) triggered by the two suffixes, as I mentioned in the introduction to this paper.

Concerning the variable "identity with the base", I have mentioned that there are some cases in which the -ção nouns do not present a total identity with the forming verbal base. In most cases, these nouns show one syllable suppressed in relation to the base. In Table 11 below, I show the frequency of this variable and it should be noted that it is relevant only for the -ção group, as the -mento group demonstrates almost $100 \%$ identity. The only exception is the word amalgamento $($ *amalgamamento $)=>$ amalgamar.

Table 11: Crosstabulation Suffix (-ção, -mento) vs. Identity with the verbal base

\begin{tabular}{ll|c|c|c}
\hline \multirow{2}{*}{ Suffix } & \multicolumn{2}{|c|}{$\begin{array}{c}\text { Identity white the } \\
\text { verbal base }\end{array}$} & \multirow{2}{*}{ Total } \\
\cline { 3 - 4 } & Yes & No & \\
\hline \multirow{2}{*}{-mento } & Count & 940 & 1 & 941 \\
\cline { 2 - 4 } & \% within Suffix & $99,9 \%$ &, $1 \%$ & $100,0 \%$ \\
\hline \multirow{2}{*}{-ção } & Count & 1.161 & 73 & 1.234 \\
\cline { 2 - 4 } & \% within Suffix & $94,1 \%$ & $5,9 \%$ & $100,0 \%$ \\
\hline \multirow{2}{*}{ Total } & Count & 2.101 & 74 & 2.175 \\
\cline { 2 - 4 } & $\%$ within Suffix & $96,6 \%$ & $3,4 \%$ & $100,0 \%$ \\
\hline
\end{tabular}

Mapping the phonological conditioning factors that triggers this phenomenon, I 
have found two factors in the data: (i) first and more productive, when the last syllable of the verbal base begins with a fricative segment [v, s, z, 3], (e.g. absorver "to absorb" => absorção "absorption"; predizer "to predict" => predição "prediction"; proteger "to protect"=> proteção "protection"); (ii) second and much less productive, when the verbal base ends in -tar (e.g. sujeitar "to subject" $\Rightarrow>$ sujeição "subjection"; interditar "to interdict" $=>$ interdição "interdiction"; atritar "to rub" => atrição "attrition"). The frequency of these conditioning factors is presented below.

Table 12: Frequency of the phonological factors

\begin{tabular}{l|c|c|c}
\hline Conditioning factors & $\mathbf{N}$ & $\mathbf{\%}$ & Valid \% \\
\hline Fricative segment & 46 & 2,2 & 64,8 \\
\hline tar & 7 & 0,3 & 9,9 \\
\hline Neither one & 18 & 0,9 & 25,4 \\
\hline Total & 71 & 3,4 & 100,0 \\
\hline Not applicable & 2.014 & 96,6 & \\
\hline Total & 2.085 & 100,0 & \\
\hline
\end{tabular}

As we can see in Table 12, almost $65 \%$ of nouns without identity with the base show a fricative segment in last syllable. Considering the low frequency $(9,9 \%=7$ cases) of the second described factor it will not be considered further in our analysis. In the next section, I discuss our theoretical proposal for interpreting these results.

\section{THEORETICAL PROPOSAL}

In this section, I propose a theoretical interpretation for the facts described in the previous section. To recap, the main results discussed were:

\section{(20) Recap of Main Results:}

Theme vowel: there is a preference relation in the -mento group for the theme vowel -e-. Further, all -mento nouns showed raising of theme vowel -e-. By contrast, the -ção group showed a lower percent within the II conjugation verbal bases (theme vowel -e-) and does not necessarily trigger the raising of theme vowel -e-.

Suffixes of verbal bases: the suffixes -izar and -mentar showed a clear tendency of occurrence within the-ção group; the termination-ecer occurred only with -mento group; and the suffixes -ciar/-cionar showed a slight preference for the -mento group.

Types of verb: there is a clear tendency of unaccusative verbs to select the -mento suffix and unergative and transitive verbs selecting the -ção suffix. Doublet: I have found in the database $19,5 \%$ of doublet forms. 
Identity with the base: $7 \%$ of the nouns belonging to the -ção group did not show identity with the base. The main phonological conditioning factor triggering this phenomenon is the presence of an initial fricative segment in the last syllable of the verbal base.

\subsection{Theoretical background}

Taking into account Chomsky's proposal $(2000,2001)$ relating to the cyclic nature of syntactic computation, in recent years, many works have discussed the cyclic properties and the locality domains concerning the word formation processes (Marantz 2001, 2007, Marvin 2002, Arad 2003, Embick 2010, among others). In such works, the authors commonly agree on two important statements: (i) the distinction between inner vs. outer domains; and (ii) the distinction between cyclic vs. non-cyclic heads.

With a clear reference to Lexical Phonology (Kiparsky 1982 and subsequent research), these works state a difference between inner and outer domains (also called low and high, cf. Arad 2003) of word formation. These two domains regard the possibility of a given functional head to be attached directly to the root (inner/low domain) or to an already categorized structure, i.e. a structure headed by a node determining its lexical category (outer/high domain). The inner domain attachment predicts idiosyncrasies in both the phonology and semantics of the word, and seems to be less productive. The outer domain, on the other hand, predicts regularities in both phonology and semantics, as it takes as input a root that has been already categorized.

The contrast between inner vs. outer domains of word formation deeply relates to this latter property of the role of category-forming heads. That is, this contrast follows from the cyclic properties imposed by phases, assuming that each cyclic category-determining head defines a phase (Marantz 2007). This means that cyclic heads merged to the syntactic structure trigger spell-out of the cyclic material in their complement position. This assumption therefore predicts constraints on the set of information available in a given cycle of PF, restricting thereby potential allomorphic interactions. On the other hand, non-cyclic heads do not define a phase (i.e. do not trigger spell-out); however, they may involve all other sorts of functional heads, like tense, aspect, number, etc.

Considering these distinctions, Embick (2010:48) states three generalizations relating to allomorphic locality:

(G1) Root-attached cyclic $x$ can see the Root.

(G2) A non-cyclic (i.e. non-category-defining) head X can see a Root in spite of intervening cyclic $x$, but this seems to happen only when $\mathrm{x}$ is non-overt ${ }^{6}$.

${ }^{6}$ An example of (G2) is provided by English past tense (Embick 2010:12-14). The T[past] node can see the root, since it shows contextual allomorphy, yielding the different allomorphs in (e.g) ben-t and hit- $\varnothing$ versus the default-ed in (e.g) play-ed. 
(G3) When there are two cyclic heads $x$ and $y$ in a structure like $[[\sqrt{\mathrm{ROOT}}$ $x] y]^{7}$ it seems that $y$ cannot see the Root, even if $x$ is not overt. That is, outer or "category-changing" cyclic heads do not seem to be sensitive to the Root.

These generalizations follow from the cyclic model for syntactic derivation (Embick 2010). Consider the following syntactic structure.

(21) Sample Structure (Embick 2010:52)

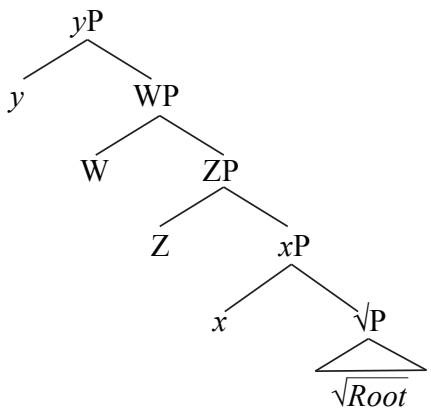

In (21), the syntactic component derives the $\sqrt{\mathrm{P}}$, and merges $x$ with it. Since $x$ is a cyclic node, spell out is triggered. So, cyclic domains in the complement of $x$ are spelled out; the result is that any cyclic domains in the $\sqrt{P}$ are subject to Vocabulary Insertion and phonological processing. Subsequent syntactic derivation merges non-cyclic $\mathrm{Z}$ and $\mathrm{W}$ to the $x \mathrm{P}$; to this object, cyclic $y$ is then merged, and again spell-out is triggered at this point. That means that $x, \mathrm{~W}$ and $\mathrm{Z}$ undergo Vocabulary Insertion in this PF cycle.

The general assumption is that only the cyclic complement of a cyclic head $x$ is spelled out in the cycle triggered by $x$. So, the root, the head $x$ itself and any edge material attached to $x$ 's domain are spelled-out only when another cyclic head is merged to the structure. However, if one assumes that DP is a phase (Embick 2010), thus, the presence of DP as complement of a root could trigger the root spell-out at the derivational point shown in (22).

${ }^{7}$ Embick (2010:15) provides an example of this generalization from English gerunds, like Jonh 's destroying the files. He claims that unlike special nominals, like laugh-ter, marri-age, destruct-ion, and so on, where nominalization involves different suffixes (i.e. a Root-determined allomorphy), gerunds always take the suffix -ing. This indicates that a root-attached cyclic head can see the root. Hence, it may demonstrate allomorphy conditioned by root. However, an outer cyclic head (e.g. the nominalizing $n$ in gerunds) is not able to see the root, even if the inner head is not overt. 


\section{(22) Root with DP complement}

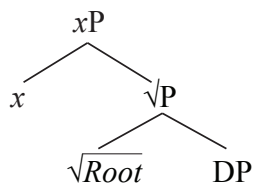

In (22), when the cyclic head $x$ is merged to the structure the cyclic domains in its complement positions (i.e. the root which takes a DP as complement) are spelled-out. Here, I would like to establish a parallel with the work of Hale and Keyser (2002) on argument structure. They argue that argument structure is determined by properties of lexical items, in particular, by the syntactic configurations in which they must appear. Discussing different types of argument structures, the authors take (23) and (24) to be structurally distinct.

(23) a. The pot broke.

b. I broke the pot.

(24) a. The engine coughed.

b. * I coughed the engine.

Unaccusative verbs like break admit the standard causative-inchoative transitivity alternation. According to Hale and Keyser (2002), this sort of verbs consists of two structural elements: a root and a verbal host. The verbal component takes a root as complement. The root complement requires a specifier, as shown in (24).

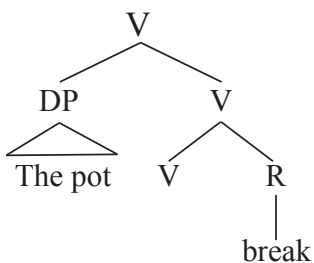

Transitivization of the type represented by (25) is in principle automatic, by virtue of two aspects: the complement relation and the presence of a specifier position. By contrast, unergative verbs (like cough, cry, dance, gallop, laugh, nap, run, etc) do not participate in transitivity alternations in virtue of the fact that the lexical head of these verbs belongs to the monadic structure in (26), with a base that is nominal in nature. This configuration lacks a specifier and therefore cannot transitivize in the simple manner. 
(26)

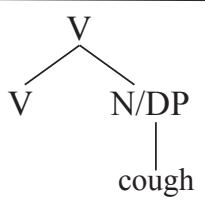

In addition to the unergatives, transitive verbs also belong to the monadic structure, taking a noun as complement and projecting no specifier position (e.g make a fuss: V[V DP]).

While the proposal of Hale and Keyser is a lexicalist approach on argument structure, it may be interesting if I can tentatively relate these considerations to the cyclic notion of the syntactic derivation. As we have seen, if a root takes a DP as complement, it can trigger the spell-out of both elements as soon as the cyclic head is merged to the structure. Thus, if one assumes, as Hale and Keyser (2002) suggest, that transitive and unergative verbs have the same type of argument structure (i.e. the monadic one), it is possible to argue that at the right point in which these roots enter in syntactic derivation, they immediately

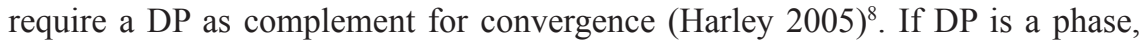
thus, the presence of DP as complement of a root may trigger the root spell-out in the first derivational stage. Consequently, transitive and unergative verbs could show distinct morphophonological properties (in relation to unaccusative verbs) in subsequent derivational processes, since their roots ${ }^{9}$ had been sent to PF to be phonologically processed in previous stages. These assumptions are the key of our analysis to the data shown in section 4, as I will discuss in the next section.

\subsection{Interpreting the Facts}

As noted in the introduction of this paper, assuming that the syntactic derivation proceeds in terms of phases (Chomsky 2000, 2001), I take the morphophonological aspects of -mento and -ção nouns to be the surface result of two syntactic properties: first, the argument structure type of the embedded verb; and second, the derivational point at which the syntactic structure is sent to PF.

Derived nouns (those which have argument structure) seem to show crosslinguistically distinct properties in relation to referential nouns (see Grimshaw 1992). Embick (2000:217) captures this fact arguing that nominalizations and other deverbal formations exhibit an aspectual projection within their syntactic structure, as shown in (27).

\footnotetext{
${ }^{8}$ Re-interpreting Jackendoff's work (1977) on one-replacement, Harley (2005) argues that roots themselves can in fact select arguments and project a $\sqrt{ } \mathrm{P}$ constituent.

${ }^{9}$ It has been assumed by hypothesis that roots do not undergo Vocabulary Insertion, but they can be phonologically processed in PF (Embick 2010, among others). However, Harley (to appear) shows a different point of view based on the phenomenon of root suppletion. She argues that if roots went into the syntax fully specified for their phonological shape, a suppletive form could not compete to realize a $\sqrt{ }$ node postsyntactically, conditioned by the syntactic context of the sentence construction.
} 
(27)

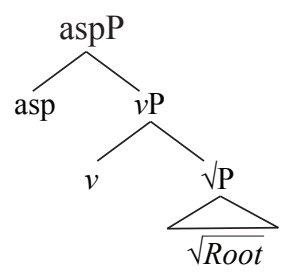

Assuming the structure in (27), I argue that the deverbal nouns formed by -mento and -ção show, in their syntactic structure, a Root attached to a cyclic head $\mathrm{v}$ and a non-cyclic head Asp, providing information of process, action, etc. The hypothesis is that the head Asp is the local domain in which the exponents /-mento/ and /-ção/ will be inserted, when the Vocabulary Insertion takes place. That is, when the cyclic head $n$ is merged to the structure.

However, as I have been discussing, there seems to be an important difference concerning the argument structure of the embedded verb. Our data has shown that there is a preference for the -mento suffix to occur with unaccusative verbs and for $-c ̧ a \tilde{o}$ suffix to occur with unergative and transitive verbs. Thus, we would have the following structures forming the two types of deverbal nouns:

(28) -mento structure

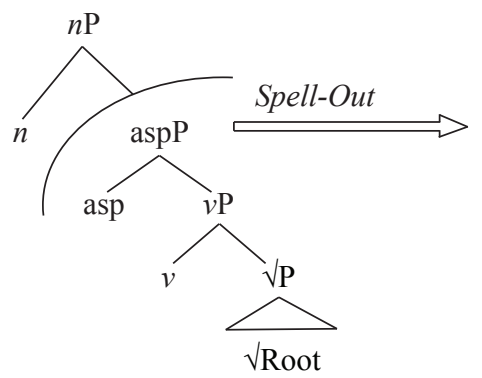

(29) -ção structure

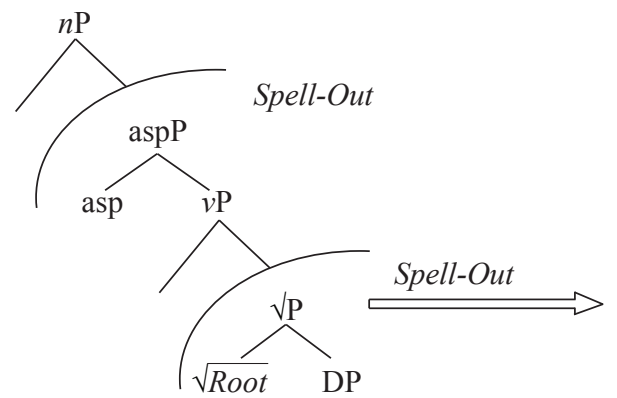


I claim that these differences relating the forming syntactic structures in which -mento and-ção enter are responsible for the morphophonological behavior of the surface nouns, because they have their root processed in distinct points in the path leading to PF. The embedded unergative/transitive verb in (29) is firstly merged to its complement, i.e. to DP. As the DP is a phase, when the cyclic head $v$ is merged to structure, the root and DP are spelled-out. By contrast, in (28), the unaccusative verb does not require a DP as complement. So, the root as well as the head $v$ and Asp are spelled-out only when the other cyclic head $n$ is attached to the derivation.

Concerning the theme vowel, there are different proposals regarding the treatment of this morpheme commonly found in Romance languages (OltraMassuet 1999, Bermúdez-Otero 2012, among others). Here, I follow Embick's proposal (2010) that theme vowels are dissociated morphemes ${ }^{10}$. The idea is that roots are specified with diacritic features relating to the different conjugation classes. Thus, in the post-syntactic component a position TH is added to $v$ where the theme vowels are implemented. According to Embick (2010), theme morphemes are "ornamental" pieces of morphology, items that are apparently relevant for morphological well-formedness, but not part of syntax.

As I have already discussed, there is a phonological rule in BP that neutralizes conjugations II and III of the verbal theme vowels (e.g. regular participle forms -ado and -ido). This rule would be stated as follows.

(30) Neutralize conjugations II and III of verbal theme vowels in non-verbal environments.

So, as a consequence of the neutralization rule in (30), if we have a paradigm of three thematic classes for verbs (disregarding the very rare vowel -o-), the deverbal formations preserve only two theme vowels: -a- and -i-. The rule implementation could also be thought in terms of classes of functional features.

(31) Input

$$
\begin{aligned}
& \text { Class -a- }[+1] \\
& \text { Class -e- }[+\mathrm{II}] \\
& \text { Class -i- }[+\mathrm{III}]
\end{aligned}
$$

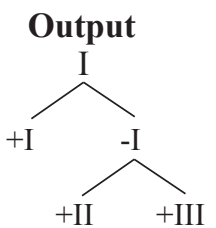

-Ção nouns, however, do not participate in such rule. Why this happens is the guiding question of this work. Considering the structure in (29) and the theoretical assumptions discussed, I argue that -ção nouns do not follow the rule in (30) because of the early derivational point in which the root is sent to PF. That is, the root is spelled-out by the $v$ head merged to the structure. Thus, it is still a verbal environment at the PF stage in which the diacritic feature of the root is processed. Hence, when the derivation proceeds and TH position is added to the structure, the inserted theme vowels are those relevant to verbs, the three differentiated classes: $[+\mathrm{I}],[+\mathrm{II}]$, or $[+\mathrm{III}]$. Therefore, the theme vowel will be immune to the neutralization rule in (30). The structure in (32) shows the lower structure of $v \mathrm{P}$ and the added thematic position. 
(32) Lower structure of $-c ̧ \tilde{a} o$ nouns: added TH position

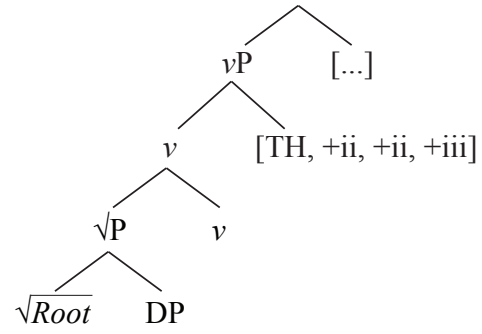

On the other hand, the -mento nouns fully comply with the neutralization rule. In my proposal, this is due to the hypothesis that there is one sole derivational point where the spell-out operation is triggered within the -mento syntactic derivation (i.e. as soon as the head $n$ is merged to the structure). Thus, in such case, the dissociated morpheme is added as part of a domain that is not anymore in a verbal environment, but a more complex structure belonging to a nominalized derivation. That is, the diacritic feature of the root is jointly processed with the nominal domain. Hence, at the moment where the Vocabulary Insertion takes place, the neutralization rule is applied and the theme vowels inserted are only those applicable to non-verbal environments, i.e. $[+\mathrm{I}]$ or $[-\mathrm{I}]$.

\section{Lower structure of -mento nouns: added TH position}

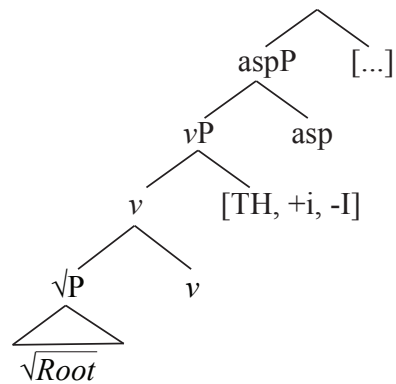

Here, it would be interesting to relate this proposal to the facts found relating to the distribution of the thematic vowel -e-. As shown, there is a preference relation (about 80\%) between the -mento nouns and the verbs with theme vowel -e-. A prospective hypothesis would regard this 'choice' to the regular behavior of -mento nouns in relation to neutralization rule. That is, if there are two competing suffixes in a language that show a complementary behavior concerning a morphophonological rule (i.e. one suffix fulfills the rule; and the other does not), it is not surprising that the suffix which feeds the rule is preferably chosen in order to maximize the rule application (see Kiparsky 1968). 
The differences regarding the embedded argument structures are also responsible for the contextual allomorphy root-conditioned. I argue, following Embick (2010) that the cyclic head $v$ attached to the root have access to it. So, the verbalizing formatives are subject to the argument structure of the root. The formative -ecer in most cases relates to unaccusative verbs: escurecer "to darken", amarelecer "to yellow", etc. By contrast, the formative -izar forms in most cases agentive verbs (both unergative and transitive): gramaticalizar "to grammaticalize", hospitalizar "hospitalize"; etc. So, the preference relation between -ção and-izar; and between - mento and-ecer is due to type of argument structure that the Asp head is selecting. The mechanism of Vocabulary Insertion is formalized as follows.

(34) Contextual Allomorphy

$$
\begin{aligned}
& {[\mathrm{ASP}] \leftrightarrow-\text { mento } /\{\sqrt{X-e c e r}, \ldots\}_{-}} \\
& {[\mathrm{ASP}] \leftrightarrow-c ̧ \tilde{a} o /\{\sqrt{-i z a r}, \sqrt{- \text { mentar }}, \ldots\}_{-}}
\end{aligned}
$$

Regarding to the formative - mentar and its impossibility to occur with - mento suffix, it seems to follow from a morphotactic constraint that does not allow two similar items together. Thus, as result of a dissimilative process, the exponent -ção is inserted to the Asp node.

A final remark regards to the fact of $7 \%$ of -ção nouns do not show identity with verbal base. I consider that phenomenon a late rule, i.e. a final phonological adjustment (Booij; Rubach 1987).

\section{CONCLUSION}

This work discussed morphophonological aspects of two nominalizing suffixes in BP: -ção and -mento. For this, I have focused on quantitative data in order to verify patterns and tendencies of behavior in a more robust number of data. Furthermore, I have attempted to argue that the different behavior of the two suffixes, regarding to the neutralization rule of theme vowels and to distinct choices of verbal bases, is due to two syntactic properties: (i) the argument structure of the embedded verb; and (ii) the derivational point in which the cyclic domains within the syntactic structure are sent to PF. Therefore, this study intended to demonstrate that a derivational approach, that considers a syntax-phonology interface perspective, seems to be relevant to understanding of the described morphophonological facts of BP.

\section{REFERENCES}

ALEXIADOU, A.; RATHERT, M (eds). (2010). The syntax of nominalizations across languages and frameworks. De Gruyter Mouton. 
FREITAS - Two nominalizing suffixes in Brazilian Portuguese: locality constraints on...

ALEXIADOU, A.; MARTIN, F. (2012).Competing affixes as aspectual morphemes. The case of deadjectival nominalizations. Online Proceedings of the $8^{\text {th }}$ Mediterranean Morphology Meeting.

ARAD, M. (2003). Locality constraints on the interpretation of the roots: the case of Hebrew denominal verbs. Natural Language \& Linguistic Theory 21: 737-778.

BASÍLIO, Margarida. Formação e classes de palavras no Português do Brasil. São Paulo: Contexto, 2004.

BECHARA, E. (2000). Moderna gramática do Português. Rio de Janeiro: Lucerna.

BERMÚDEZ-OTERO, R. (to appear).The Spanish lexicon stores stems with theme vowels, not roots with inflectional class features. Forthcoming in Probus 25(1).

BOOIJ G.; RUBACH, J. (1987).Postcyclic versus Postlexical Rules in Lexical Phonology. Linguistic Inquiry, Vol. 18, No. 1 (Winter, 1987), pp. 1-44.

DUARTE, I. (2003). A família das construções inacusativas. In: MATEUS, M.H.M. et al. Gramática da língua portuguesa. Lisboa: Caminho. p.507-548.

EMBICK, D. (1998)." Voice systems and the syntax/morphology interface". In H. Harley (ed.) The Proceedings of the Penn/MIT Workshop on Aspect, Argument Structure, and Events, MITWPL.

EMBICK, D. (2000). Features, syntax and categories in the latin perfect. In: Linguistic inquiry. Cambridge, Massachusets: MIT Press, v.31, n.2, p.185-230.

EMBICK, D. (2010). Localism versus Globalism in Morphology and Phonology. Cambridge, MA: MIT Press.

EMBICK, D.; MARANTZ, A. (2008) “Architecture and Blocking,” Linguistic Inquiry 39:1,1-53.

GAMARSKI, Léa. A derivação regressiva: umestudo da produtividade lexical em português. PhD. Dissertation. Rio de Janeiro, UFRJ, 1984.

GRIMSHAW, J. (1992). Argument Structure. Linguistic Inquiry Monograph Eighteen. Cambridge, MA: MIT Press.

HALE, K.; KEYSER, S. J. (1993).On argument structure and the lexical expression of grammatical relations. The view from Building 20. Essays in honor of Sylvain Bromberger, ed. by Kenneth Hale and Samuel Jay Keyser,53-110. Cambridge, MA: MIT Press.

HALE, K.; KEYSER, S. J.. (1998).The basic elements of argument structure. Papers from the UPenn/ MIT Roundtable on Argument Structure and Aspect, MIT Working Papers in Linguistics 32, ed. by Heidi Harley, 73-118. Cambridge MA: MIT, Department of Linguistics and Philosophy, MITWPL.

HALE, K.; KEYSER, S. J.. (2002). Prolegomenon to a theory of argument structure. Cambridge, MA: MIT Press.

HALLE, M. (1997). "Distributed Morphology: Impoverishment and Fission." MIT Working Papers in Linguistics 30, p. 425-439.

HALLE, M.; MARANTZ, A. (1993). "Distributed Morphology and the Pieces of Inflection," in Kenneth Hale and Samuel Jay Keyser, eds., The View from Building 20: Essays in Linguistics in Honor of Sylvain Bromberger, MIT Press, Cambridge, MA, 111-176. 
HALLE, M.; MARANTZ, A. (1994). Some key features of distributed morphology. MIT Working Papers in Linguistics 21: Papers on phonology and morphology. p. 275-288. Cambridge, MA: MIT Press.

HARLEY, H. (to appear) "On the identity of roots". Theoretical Linguistics.

HARLEY, H. (2005)."Bare Phrase Structure, Acategorial roots, one-replacement and unaccusativity," Harvard Working Papers on Linguistics Vol. 9, ed. by Slava Gorbachov and Andrew Nevins.

KENSTOWICZ, M. (1996). "Base-identity and uniform exponence: Alternatives to cyclicity," in J. Durand and B. Laks, eds., Current trends in phonology: Models and methods, University of Salford Publications, 363-93.

KIPARSKY, P. (1968) "Linguistic universal and linguistic change." In Emmon Bach and Robert T. Harms, eds., Universals in Linguistic Theory, New York: Holt, Rinehart and Winston, 170-202.

KIPARSKY, P.(1973)." "Elsewhere in Phonology", in S.R.Anderson and P. Kiparsky, eds., A Festshrift for Morris Halle. New York: Holt, Rinehart and Winston, 93-106.

KIPARSKY, P. (1982).Lexical Phonology and Morphology. In-Seok Yang (ed.), Linguistics in the Morning Calm. Seoul.

KIPARSKY, P. (1982).Word-formation and the Lexicon. In F. Ingemann (ed.) Proceedings of the MidAmerica Linguistics Conference, Lawrence, Kansas.

LEVIN, B.; RAPPAPOT HOVAV, M. (1995). Unaccusativity: At the Syntax-Lexical Semantics Interface, Linguistic Inquiry Monograph 26, MIT Press, Cambridge, MA.

MARANTZ, A. (1997). "No Escape from Syntax: Don"t Try Morphological Analysis in the Privacy of Your Own Lexicon," in Alexis Dimitriadis, Laura Siegel, Clarissa Surek-Clark, and Alexander Williams, eds., Proceedings of the 21st Penn Linguistics Colloquium, UPenn Working Papers in Linguistics, Philadelphia, 201-225.

MARANTZ, A. (2007). "Phases and words," in S. H. Choe et al, ed., Phases in the theory of grammar, Dong In Publisher, Seoul.

MARVIN, T. (2002) Topics in the stress and syntax of words. Doctoral dissertation, MIT.

MATOSO CÂMARA JR. (1970). Estrutura da língua portuguesa. Petrópolis: Vozes.

NOYER, R. (1992) Features, Affixes, and Positions in Autonomous Morphological Structure. Doctoral dissertation, MIT.

OLIVEIRA, S. M. (2007). Os sufixos nominalizadores -ção e-mento. Estudos Linguísticos XXXVI(1).

OLTRA-MASSUET, I. (1999). On the notion of theme vowel: A New Approach to Catalan Verbal Morphology. Master thesis. MIT, Cambridge, MA.

ROCHA, Luiz Carlos de Assis. (1999). A nominalização no português do Brasil. Revista de Estudos da Linguagem 8: 1, p. 5-52.

SANTOS, C.M.B. (2006). Os sufixos -ção e -mento na construção de nomes de ação e processo: contribuições à prática lexicográfica. Master thesis. Porto Alegre: UFRGS. 